DOI: $10.15503 /$ jecs20162.288.297

\title{
OPEN EDUCATIONAL RESOURCES: BETWEEN MCSCHOOL AND CREATIVE SCHOOL
}

\author{
ANNA ANETTA JANOWSKA \\ Institute for International Studies, Warsaw School of Economics, \\ Rakowiecka Street 24, Warsaw, Poland \\ E-mail address: ajanows@sgh.waw.pl
}

(c)

\begin{abstract}
The purpose of the paper is to analyse whether open educational resources (OER), perceived by their enthusiasts as a key factor to economic, social and environmental progress, are a sufficient element to trigger a revolution in education - the world education systems suffering from the process of McDonaldization which impedes them from evolving towards the XXI century "creative school" structure. The analysis, based on a number of surveys conducted and published in Poland between 2013 and 2015 (Poland being in fact used as a case study) reveals, firstly, that the usage of OER is less frequent and common than it is supposed to be. Secondly, these resources serve as a complement to the traditional methodologies rather than a source of creative change, their real potential remaining undiscovered. Last but not least, to flourish, this potential demands a switch of paradigm at each level of the educational ecosystem, which principally means more freedom for teachers to create their own methodologies, including creative usage of OER, and ways of assessing students.
\end{abstract}

Key words: open educational resources, OER, McDonaldization, McSchool, creative school

Open Educational Resources, developed for about ten years all around the world by institutions and enthusiasts, have become an important phenomenon in education. They are seen as a key factor to economic, social and environmental progress, for which reason they are objects of exceptional care by governments. Yet education, not only at its high level, but also in its primary and secondary cycle, has suffered for several years from the all-embracing and overwhelming process of McDonaldization that impedes educational systems from evolving towards the XXI century's needs and exigencies, namely the individual, creative process of teaching and learning.

In the McDonald's-style educational environment, the concept of the creative school appears to be an entirely ground breaking idea, which surprisingly coincides with that of the openness of educational resources. It was the authors of the book Opening Up Education who already highlighted that open education leads to a deep transformation in education (Iiyoshi, \& Kumar, 
2008, p. 3). The statement has also appeared in several studies (OECD, 2007; Butcher, 2011; Masterman, Wild, White, \& Manton, 2011; Schmidt-Jones, 2012; Grodecka, \& Śliwowski, 2013) where OER are claimed to help educational systems in becoming more dynamic, which can lead to a full redefinition of the teaching and learning environment, making it 'future-proof' (Orr, Rimini, \& Van Damme, 2015, p. 16).

The purpose of the paper is to analyse whether open educational resources which, in fact, are in the major part developed by the grassroots processes, are a sufficient element to trigger a revolution in education. Poland, as one of the leading countries in innovations for education (Hofmokl, Siewicz, Szprot, Tarkowski, Bednarek-Michalska, \& Bendyk, 2009, p. 65), will be used as a case study, based on a number of surveys conducted and published in Poland between 2013 and 2015: E-manuals and Digital School (pol. E-podręczniki i Cyfrowa Szkoła) (MEN, 2013), New Technologies at School (pol. Nowe technologie w szkole) (Maciejewska, Reda, \& Kalinowski, 2014), Survey about the Influence of the Digital School Programme on the Lower Secondary Final Exam Results (pol. Analiza wptywu programu Cyfrowa Szkoła na wyniki sprawdzianu szóstoklasisty) (Penszko, \& Zielonka, 2015), Time and work conditions in teachers' opinions (pol. Czas pracy $i$ warunki pracy $w$ relacjach nauczycieli) (Federowicz, Haman, Herczyński, Hernik, Krawczyk-Radwan, Malinowska, Pawłowski, Strawiński, Walczak, \& Wichrowski, 2013) and Teachers matter. Report on the State of Education in 2013 (Czajkowska, Choińska-Mika, Walczak, Bordzoł, Hernik, Kłobuszewska, Kobus, Kopańska, Lorenc, Malinowska, Mrozowski, Musialik, Oniszczuk, Orzechowska, Ostrowska, Paczuska, Poziomek, Przewłocka, Piwowarski, Rokicka, Sitek, Smak, Staniszwski, Starczynowska, Szpotowicz, Wichrowski, \& Zasacka, 2014).

\section{MCSCHOOL AND CREATIVE SCHOOL - DEFINITIONS AND CHARACTERISTICS}

"McSchool" is a term referring to McDonaldization, which is a concept developed by George Ritzer in his book McDonaldization of Society (1993). The author argues that the principles of the fast-food restaurant are dominating increasingly many sectors of the American society as well as the rest of the world (Ritzer, 1993, p.1). He indicates four such principles: efficiency, predictability, calculability and control. Efficiency means that every process of the business happens at the right place and the right time to ensure the maximum satisfaction for the consumer and the maximum profit for the company. Predictability signifies uniformity of products in each unit of the company, be it the USA or Poland, which excludes innovation or initiative from employees. When it comes to calculability, it relates to standardization of products meaning a precisely calculated number of processes of production as well as identical dimensions, composition and weight. They are supposed to guarantee the same quality, whereas, in fact, this is quantity that is mistaken for 
quality. The last principle, control, is achieved through the substitution of nonhuman for human technology (Ritzer, 1993, p.11). It refers to employees who have to perform the same repetitive actions, as well as to customers who are expected to behave in a predefined way: they chose from a limited number of items in the menu, carry food to the table and litter away from it.

G. Ritzer claims that education is guided by the same principles. He describes universities as means of educational consumption allowing students to consume educational services and to obtain important "goods" degrees and credentials (Ritzer, 1998 p. 151). This tendency combined with, on the one hand, a global pressure on countries to augment the number of university graduates and, on the other, the decreasing funding of the educational sector directly leads to an optimization of processes aimed to be as effective as possible. This objective may be and is achieved by adoption of the four main McDonald's principles. What is worth noticing is that the McUniversity concept mirrors the whole educational sector: there are McSchools, from the primary school to upper secondary, which follow this pattern. To achieve efficiency, the number of students in classes is relatively large which means that, for example, language workshops or ethics classes in Polish schools are limited in the curriculum. Predictability is reflected in the uniform core curriculum for every school in the country, without taking into account local specificities. Moreover, a finite list of manuals is approved by the authorities. The students' knowledge is assessed by means of tests, which proves not only a kind of specific control and 'dehumanisation' of the assessment process, but also the calculability which signifies that a precise number of hours devoted to a certain subject should result in a specified percentage of points. These points are subsequently expected to reflect the quality of education whereas what they actually measure is a minor part of the whole field.

When it comes to the concept of the creative school, Sir Ken Robinson made it globally popular thanks to his first TED speech entitled Do Schools Kill Creativity (2006), where he states that creativity "is as important in education as literacy and we should treat it with the same status" (2006). This concept of the creative school remains completely opposite to today's McSchools, as it denies standardization, quantity instead of quality and control. In the book Creative Schools (Robinson, \& Aronica, 2015), the authors call for an end to the outmoded industrial educational system and propose a highly personalized, organic approach that draws on today's unprecedented technological and professional resources (Robinson, n.d.). They insist upon supporting individuality at school, as well as developing imagination and creativity (Robinson, \& Aronica, 2015, p. xxii), which in fact leads the students to discover their own talents and thus achieve the true vocation of education: "to enable students to understand the world around them and the talents within them so that they can become fulfilled individuals and active, compassionate citizens" (Robinson, \& Aronica, 2015, p. xxiv). This objective is proposed to be reached by a revolutionary grassroots process based on, among others, tech- 
nology, project-based learning models, skills such as solving problems and communication, and giving teachers more freedom (Robinson, \& Aronica, 2015, p. 228).

\section{OPEN EDUCATIONAL RESOURCES (OER) - DEFINITIONS AND CONTEXT}

In literature, several definitions of OER may be found (Gurell, 2008, p.2; OECD, 2007, p.30; Orr, Rimini, \& Van Damme, 2015, p. 17; Grodecka, \& Śliwowski, 2010, p. 7). They suggest that educational resources, to be considered as OER, have to comply with the requirements of the "open content" $5 \mathrm{R}$ framework, developed by David Wiley in 1998 for works published under so called Open Content License (OpenContent, 1999) and presented in the table below.

Table 1. 5Rframework

\begin{tabular}{|ll|}
\hline permissions & description \\
\hline Retain & $\begin{array}{l}\text { the right to make, own, and control copies of the content (e.g., download, } \\
\text { duplicate, store, and manage) }\end{array}$ \\
\hline Reuse & $\begin{array}{l}\text { the right to use the content in a wide range of ways (e.g., in a class, in a study } \\
\text { group, on a website, in a video) }\end{array}$ \\
\hline Revise & $\begin{array}{l}\text { the right to adapt, adjust, modify, or alter the content itself (e.g., translate the } \\
\text { content into another language) }\end{array}$ \\
\hline Remix & $\begin{array}{l}\text { the right to combine the original or revised content with other material to } \\
\text { create something new (e.g., incorporate the content into a mashup) }\end{array}$ \\
\hline Redistribute & $\begin{array}{l}\text { the right to share copies of the original content, your revisions, or your remixes } \\
\text { with others (e.g., give a copy of the content to a friend) }\end{array}$ \\
\hline
\end{tabular}

Source: Defining the "Open" in Open Content.

OER may be thus defined as digitised materials for teaching, learning and research, publically available on the Internet, free of charge and without access restrictions, accompanied by a free license and developed in an open manner to permit their free reuse, continuous improvement and repurposing by others for educational purposes.

Poland has quite a strong position among other countries when it comes to openness movements that started to flourish a few years ago thanks to a number of non-governmental organisations, such as Digital Centrum Project: Poland (pol. Centrum Cyfrowe Projekt: Polska), Modern Poland Foundation (pol. Fundacja Nowoczesna Polska), Association Wikipedia Poland (pol. Stowarzyszenie Wikimedia Polska) and Association of Polish Librarians (pol. Stowarzyszenie Bibliotekarzy Polskich). In 2008, the last three of them founded the Polish Coalition for Open Education, which is an agreement between non-governmental organisations and institutions working in the field of education, science and culture. Today, KOED is an umbrella term for about 35 entities working together for promotion of OER in Poland. 
In 2012, the Polish Ministry of National Education launched the Digital School (pol. Cyfrowa Szkoła) - a pilot programme of a multi-year project aimed at developing students' and teachers' competences in the field of ICT usage at school. 398 schools were invited to take part in the pilot phase by receiving a subsidy to purchase modern teaching resources, such as mobile equipment, to be used in classes and out of them. The goal of the whole programme was not only to provide schools with technical means, but also to train teachers and students in digital literacies and to produce a set of e-manuals as well as additional open materials for primary and secondary schools, accessible for students and teachers on a public open portal (Cyfrowa Szkoła).

What is worth highlighting is that the OER definitions mentioned above present the supplier perspective, focusing rather on properties of the resources themselves. These aspects, despite being undoubtedly important, are insufficient to add significant value to this free and open educational content. In fact, it is solely the usage that makes resources valuable, and the potential of OER is determined by the way they are used (Orr, Rimini, \& Van Damme, 2015, p. 16), for which reason OER should be regarded from this viewpoint as well. A value-building usage of OER rests on three interconnected and overlapping elements: technical infrastructure, digital literacies and, last but not least, educational policy and organisational structure of the sector.

The technical infrastructure necessary to make schools future-oriented involves providing them and their students with equipment: computers or laptops, to be used both in IT classes and outside of them. Apart from the hardware, what is equally important is a broadband access to the internet in schools. Regarding the digital literacies, they embrace various competences of teachers and students relative to good and valuable usage of digital content such as technical skills, operating software, knowledge about diverse resources accessible online and basic notions of copyright, free licences and security on the Internet. The last element, educational policy, is principally shaped by Ministries of Education or similar institutions in respective countries. Unfortunately, their policies risk being quite narrowly oriented, emphasising strictly educational aspects. Introducing openness into the area of education demands a broader cooperation between diverse entities, e.g. - which is the case in Poland - the Polish Ministry of Administration and Digitisation.

\section{USAGE OF ICT AND OER IN POLISH SCHOOLS}

As we have seen, the "push" perspective of the OER phenomenon is well anchored into the educational landscape. This brings us to the issue of the "pull" point of view, namely whether digital content and especially open educational resources are used at schools and, if so, to what extent. Recently, a series of surveys focusing on technology at school were con- 
ducted in Poland by institutions such as the Ministry of National Education, School and Pedagogical Publishers (pol. Wydawnictwa Szkolne i Pedagogiczne) and Educational Research Institute (pol. Instytut Badan Edukacyjnych). The main conclusion is that the evaluation of the OER usage in Polish schools appears to be quite a daunting task due to two main reasons. First, there is a lack of data coming from viable surveys that could be compared and deeply analysed, second, these surveys are based on a declarative method that reflects a certain image of respondents by themselves, rather than real behaviour. Similar difficulties were raised by foreign researchers, e.g. Catherine. A. Schmidt-Jones (2012).

Nevertheless, certain observations and conclusions may be drawn from these analyses. Although teachers are familiar with OER accessible online, especially with two platforms: Wikipedia and Scholaris ${ }^{1}$, only a slight minority of them seem to use OER very often. What is more significant is that teachers consider them an additional and fashionable source of information rather than an innovative inspiration for new methodologies applied in class, whose usage could be triggered by a much more creative approach to the school methodology based on OER, together with project-based learning models and/ or case studies focused on solving problems and communication. Teachers admit to a strong preference for using open content as a complementary material rather than the core one, by mainly focusing on searching interesting content and presenting it by means of a Power-Point slideshow (playing, surprisingly, the role of a "high degree innovation" at schools). In fact, multimedia presentations (Power-Point alike), multibooks ${ }^{2}$ and content downloaded from the internet, such as photos and YouTube videos, enjoy the greatest popularity.

What is worth mentioning is that delivering effective speeches or interesting lectures based on Power-Point presentations is a sort of art which, unfortunately, remains a scarce competence. This statement is vastly confirmed by communication specialists, e.g. Jerry Weisman (2007) or Matt McGarrity (McGarrity, n.d.). Moreover, the application of such a tool in class is consistent rather with the traditional approach of 'one to many' method, where students remain a passive audience. A well prepared and well delivered presentation has a potential to make the transfer of knowledge more effective, especially thanks to its visual form, but does not have a lot in common with the creative school concept coined by K. Robinson. Furthermore, teachers do not necessarily need to rely on OER to design interesting presentations as the 'fair use' rule allows them to use copyrighted materials in class.

1 Scholaris - is a Polish knowledge portal for teachers, offering free educational resources that are consistent with the core curriculum and compatible with school equipment (interactive boards and tablets). The project has been developed by Education Development Center (pol. Ośrodek Rozwoju Edukacji), supported by the Polish government progamme Digital School and funded with European Funds (see:'Scholaris').

2 Multibooks, according to the publisher definition, are digital publications including manual content, exercises, accompanied with films, animations, audio tracks, slideshows and photos. They are commercially produced and distributed educational materials; see (Multibook podstawowe informacje - Wydawnictwo Nowa Era | Multibook, n.d.). 
In the teachers' opinion, e-content can favour the creative usage of accessible sources of knowledge and help develop creativity and skills for school subjects, but it is less frequently perceived as a springboard for stimulating critical thinking, increasing participation in culture and supporting reading habits or building up cooperation skills.

The results reveal that teachers continue to operate in the McSchool logic, their individual creativity being replaced by a sort of automated processes. Such a state of affairs could be explained by, on the one hand, the organisational situation in schools and the whole educational system as such, where teachers are obliged to both follow the overloaded core curriculum and assess students by means of standardised tests. On the other hand, they seem to be too accustomed to the "classic" methods of giving classes.

Symptoms of the same traditional way of approaching the issue of ICT and OER may be seen in the analysis evaluating the Digital School Programme influence on the lower secondary final exam results (2015). Unfortunately, no significant and long term improvement was observed, apart from a slight positive change in favour of some low-scoring students who obtained better results in the 2013 "reasoning" section of the exam. The authors of the study concluded, after having compared the data with similar initiatives in other countries, that 'such public interventions do not significantly affect exam results within 15-18 months' (Penszko, \& Zielonka, 2015). Nevertheless, a closer look at the methodology suggests that only such competences as writing, reading and calculating were covered by the analysis, which raises significant questions about the relevance of the evaluation. One should not forget that technology, equipment and resources such as OER remain merely a tool. Used in an adverse way, meaning here from "classical" McSchool perspective and with inappropriate methodology hampering a boost of their efficiency, they should not be collectively assessed as ineffective.

What was pointed out in one of the surveys is that teachers do not feel the necessity to be trained about OER, and especially about e-manuals, a vast majority of them declaring written instructions (e.g. online) or e-learning training be sufficient. This approach seems to show once again the traditional logic guiding teachers' behaviour which belongs to the McSchool pattern. These resources are perceived solely as an additional tool to be applied in class, their novelty placed mainly in the digital format. By that means, training is imagined as concerning technical skills rather than methodological ones that should inspire creative and innovative application of new tools.

The greatest misunderstanding concerning OER relates to the wrong interpretation of the term as such. "Open" is translated as broad accessibility (online) and free ("gratis") usage. This perception is reflected in a vast majority of answers referring to the usage of, broadly speaking, e-content. Yet the crucial advantage of the OER lies especially in two of the five "freedoms" cited above, namely reuse and remix. These terms signify that the 
resources are permitted to be applied in creative ways: adapted, adjusted, modified, altered as well as combined with other material to create something new (OpenContent, 1999). Unfortunately, only a small minority of respondents of the surveys who claimed to use OER revealed that they used e-manuals to create or modify content, or produce their own materials, which places teachers rather closer to a McSchool than to a creative one. This observation may also be supported by the answers about usage of social media showing that solely $1 \%$ of teachers are present on them. These platforms demand, in fact, an active usage of ICT, be it simple, short comments to the friends' photos or status. Poor online activity of Polish teachers understood as creative contribution follows in fact the global trend of definitely passive usage of the new technologies (OECD, 2015, p.139), which reflects the "old-fashioned" attitude towards the teaching process rather than the 'modern' creative one.

\section{CONCLUSION}

Regarded globally from the push perspective or, in other words, as developers', distributors' and supporters' initiative, the OER movement appears to be quite a popular phenomenon. In Poland, these resources are developed principally by NGOs involved in education and new technologies, and sustained by the government which not only funds certain OER projects, but also promotes them among Polish schools. Reputable organisations such as UNESCO or OECD promote them as having a powerful transformative potential (Butcher, Kanwar, \& Uvalic-Trumbic, 2011) and being a catalyst for social innovation, which can facilitate changed forms of interaction between teachers, learners and knowledge (Orr, Rimini, \& Van Damme, 2015, p. 11). In brief, "using open resources in instruction can create the customized and personalized learning that has the promise to open up our classrooms to those students who so need to be freed from its current construct" (Stout, 2016).

Unfortunately, studies conducted among teachers in Poland, from the "pull perspective", reveal that the usage of OER is not as frequent and common as it is supposed to be. They serve rather as a freely accessible source of teaching materials than a true innovation in education, which may be observed in Poland. This is mainly due to the fact that their real potential, lying in the " $5 \mathrm{R}$ open content framework", remains undiscovered or, at best, severely undermined. Teachers seem to use open e-content to continue to operate in the McSchool logic instead of building a new, "creative school" one. Unfortunately, this change demands a switch of paradigm as OER practice must be crafted and developed in a receptive educational environment (Orr, Rimini, \& Van Damme, 2015, p.16), evolving itself towards "future-oriented creative education". 


\section{REFERENCES}

[1] Biuro Prasowe Orange Polska. World Internet Project 2013 pod znakiem mobilności i mediów społecznościowych [Orange Polska Press Office] (2013). Retrieved from http:/ / biuroprasowe.orange. pl/biuroprasowe/pr/2492world-internet-project-2013-pod-znakiem-mobilnosci-i-mediowspolecznosciowych/.

[2] Butcher, N., Kanwar, A., \& Uvalic-Trumbic, S. (2011). A basic guide to open educational resources (OER). Vancouver, Paris: Commonwealth of Learning, UNESCO.

[3] Cyfrowa Szkota [Digital School] (n.d.). Retrieved from http://www.ceo.org.pl/pl/ cyfrowaszkola/news/cyfrowa-szkola.

[4] Czajkowska, M., Choińska-Mika, J., Walczak, D., Bordzoł, P., Hernik, K., Kłobuszewska, M., Kobus, M., Kopańska, A., Lorenc, J., Malinowska, K., Mrozowski, K., Musialik, M., Oniszczuk, A., Orzechowska, M., Ostrowska, B., Paczuska, K., Poziomek, U., Przewłocka, J., Piwowarski, R., Rokicka, M., Sitek, M., Smak, M., Staniszwski, J., Starczynowska, K., Szpotowicz, M., Wichrowski, A., \& Zasacka, Z. (2014). Teachers matter. Report on the State of Education in 2013. Warszawa: Instytut Badań Edukacyjnych.

[5] Defining the 'Open' in Open Content (n.d.). Retrieved from http://opencontent.org/ definition/.

[6] Federowicz, M., Haman, J., Herczyński, J., Hernik, K., Krawczyk-Radwan, M., Malinowska, K., Pawłowski, M., Strawiński, P., Walczak, D., \& Wichrowski, A. (2013). Czas i warunki pracy $w$ relacjach nauczycieli [Time and Work Conditions in the Teachers' Statements]. Retrieved from http:/ / eduentuzjasci.pl/badania/110-badanie/186-badanie-czasu-i-warunkow-pracynauczycieli.html.

[7] Grodecka, K., \& Śliwowski, K. (2013). Open Educational Resources in Poland: Challenges and Opportunities. Moskwa: UNESCO Institute for Information Technologies in Education. Retrieved from https://pl.scribd.com/doc/300269585/Open-Educational-Resources-inPoland-Challenges-and-Opportunities.

[8] Grodecka, K. \& Śliwowski, K. (2012). Przewodnik po Otwartych Zasobach Edukacyjnych [Guide to Open Educational Resources]. Koalicja Otwartej Edukacji. Retrieved from http://www. kpbc.ukw.edu.pl/dlibra/publication?id=62474\&from=\&dirids=1\&tab=1\&lp=2\&QI=.

[9] Gurell, S. (2008). Wprowadzenie do otwartych zasobów edukacyjnych [Introduction to Open Educational Resources]. Retrieved from http://kpbc.umk.pl/dlibra/doccontent?id=40051\&fro $\mathrm{m}=$ pubindex\&dirids $=65 \& \mathrm{l} \mathrm{p}=143$.

[10] Giving Knowledge for Free. The Emergence of Open Educational Resources (2007). OECD, Organisation for Economic Co-operation and Development. Retrieved from http://www.oecd-ilibrary.org/docserver/download/9607041e.pdf?expires=1471545988\&id=id\&accname=gu est\&checksum=2597101EF939F435BF8F414362A6459E.

[11] Hofmokl, J., Siewicz, K., Szprot, J., Tarkowski, A., Bednarek-Michalska, B., \& Bendyk, E. (2009). Przewodnik po otwartej nauce (Guide to Open Access). Retrieved from http://creativecommons.pl/wp-content/uploads/2012/06/Przewodnik_Po_Otwartej_Nauce.pdf.

[12] Iiyoshi, T. \& Kumar, M.S.V. (Eds.). (2008). Opening up education: the collective advancement of education through open technology, open content, and open knowledge. Carnegie Foundation for the Advancement of Teaching. Cambridge, Massachusets: MIT Press. Retrieved from https:/ / mitpress.mit.edu/sites/default/files/titles/content/9780262515016_Open_Access_Edition.pdf.

[13] Maciejewska, M., Reda, M., \& Kalinowski, P. (2014). Nowe technologie w szkole [New Technologies at School]. Warszawa: Wydawnictwa Szkolne i Pedagogiczne. Retrieved from https:/ / www.wsip.pl/upload/2014/01/Nowe-technologie-w-szkole-3.pdf.

[14] Masterman, L. \& Wild, J. (2011). Open Educational Resources Programme: Phase 2. OER Impact Study: Research Report. JISC, University of Oxford. Retrieved from http://www.webarchive. org.uk/wayback/archive/20140614114910/http://www.jisc.ac.uk/media/documents/ programmes/elearning/oer/JISCOERImpactStudyResearchReportv1-0.pdf.

[15] McGarrity, M. (n.d.) Introduction to public speaking. Coursera MOOC platform. Retrieved from https://www.coursera.org/learn/public-speaking.

[16] Multibook - podstawowe informacje [Multibook - basic information]. (n.d.). Retrieved from http://nowaera.pl/multibook/multibook-podstawowe-informacje.html. 
[17] Ośrodek Rozwoju Edukacji. E-podręczniki i 'Cyfrowa szkoła' - wyniki ankiety [Centre for Education Development. E-manuals and 'Digital School']. (2013). Retrieved from https:// www.ore.edu.pl/wydzialy/wychowania-i-profilaktyki/zespol-ds-promocji-zdrowia-wszkole/2954-e-podrczniki-i-cyfrowa-szkoaq-wyniki-ankiety.

[18] OECD Digital Economy Outlook (2015). Retrieved from http://www.keepeek.com/Digital-Asset-Management/oecd/science-and-technology/oecd-digital-economy-outlook-2015_9789264232440-en\#.V7GvpiNLpBc.

[19] OpenContent (1999). Retrieved from http://web.archive.org/web/19990128224600/http:/ / www.opencontent.org/home.shtm.

[20] Orr, D., Rimini, M., \& Van Damme, D. (2015). Open Educational Resources: A Catalyst for Innovation. Retrieved from http://www.keepeek.com/Digital-Asset-Management/oecd/education/open-educational-resources_9789264247543-en\#.V7NCRPmLRhE\#page2.

[21] Penszko, P. \& Zielonka, P. (2015). Analiza wptywu programu 'Cyfrowa Szkoła' na wyniki sprawdzianu szóstoklasisty [Analysis of the Influence of "Digital School" Programme on the $6^{\text {th }}$ Grade Test Results]. Retrieved from http://www.ibe.edu.pl/pl/publikacje/analizy-ibe.

[22] Ritzer, G. (1998). The McDonaldization Thesis. London Thousand Oaks, New Delhi: Sage Publications.

[23] Ritzer, G. (1993). The McDonaldization of Society. Thousand Oaks: Pine Forge Press.

[24] Robinson, K. (2006). Do schools kill creativity? TED Ideas Worth Spreading. Retrieved from https://www.ted.com/talks/ken_robinson_says_schools_kill_creativity.

[25] Robinson, K., \& Aronica, L. (2015). Creative Schools: The Grassroots Revolution That's Transforming Education. New York: Viking.

[26] Schmidt-Jones, C.A. (2012). An open education resource supports a diversity of inquiry-based learning. The International Review of Research in Open and Distributed Learning, 13 (1), 1-16.

[27] Scholaris. O nas [About us] (n.d.). Retrieved from http://www.scholaris.pl/onnas.

[28] Robinson, Sir K. (n.d.). Creative Schools: The Grassroots Revolution That's Transforming Education. Retrieved from http://sirkenrobinson.com/creative-schools-the-grassrootsrevolution-thats-transforming-education/.

[29] Stout, K.A. (2016). The Role of Open Educational Resources in the Student Success Agenda. Retrieved from http://www.huffingtonpost.com/entry/the-role-of-open-educational-resourcesin-the-student_us_579688e7e4b0b3e2427cde56.

[30] Weisman, J. (2007). Sztuka skutecznej prezentacji [Presenting to Win: The Art of Telling Your Story]. Gliwice: Helion. 